\title{
Olah Data Matematika dan Statistik Sebagai Penunjang Kewirausahaan
}

\author{
Etika Sabariah \\ Universitas Bina Sarana Informatika \\ etika.esb@bsi.ac.id
}

\begin{abstract}
Like to known, businessman increase growth up always every time. Because high cost living, depreciation value money, there are opportunity, high competitor at world working make the people choice become businessman. Like to known think obout strategic is must to do. On business, activity always influence by environmental until need manajemen and technology application and rich knowledgement economic science, manajemen strategic and another supporter factor. So to support strategic business, businessman need training about data manner with using mathematic and statistic to help make decisition. So actor from academic very help them, with training that is giving as shape tri duty

Keywords: Growth up businessman, strategic, data manner, training, actor academic, tri duty
\end{abstract}

\section{PENDAHULUAN}

Seperti diketahui wirausaha bemunculan dimana-mana, ada yang bergerak dibidang usaha dagang, jasa atau dibidang pabrikasi (skala padat karya atau skala padat modal), tapi kembali lagi pada kenyataan yang ada bahwa banyak sekali wirausaha jatuh bangun dan saling mengganti satu sama lainnya. Dan fakta ini membuat keprihatinan semakin nyata, karena usaha masyarakat untuk melepaskan diri dari kepurukan ekonomi, dengan wirausaha pada keterbatasan yang cukup significant dari berbagai segi membuat mereka semakin terpuruk ekonominya karena tidak saja modal usaha yang habis, melainkan juga setumpuk hutang usaha menjadi beban mereka.

\section{TINJAUAN PUSTAKA}

A. Berfikir strategis adalah sebuah keharusan dalam menjawab semua permasalahan kehidupan secara luas. Hal tersebut terjadi karena beberapa faktor seperti: (1) sudah semakin nyata bahwa sumber daya semakin terbatas untuk didapat, sampai-sampai barang yang dulu adalah sumber daya bebas yang mudah diperoleh tanpa pengorbanan yang berarti, sekarang telah menjadi sumber ekonomi, (2) Makin tingginya kebutuhan hidup sebagai akibat dari banyaknya manusia, adanya bencana alam, peperangan dan perubahan nilai tukar barang, jasa, dan uang, (3) Makin besarnya konflik yang terjadi dalam berinteraksi, bernegoisasi, melakukan aktivitas ekonomi, yang merupakan sebagai akibat dari persaingan dalam mendapat sumber daya yang sudah tidak mengenal batas (globalisasi), (5) perbedaan kepentingan atau pencapaian tujuan dari tiap individu, institusi atau perusahaan. (sabariah, etika, 2016) 
B. Berfikir strategis adalah memikirkan masa atau waktu yang akan datang, tentang apa yang harus dilakukan, keputusan apa yang harus diambil, apa yang harus dibelanjakan, apa yang harus dipersiapkan, apa yang harus dipilih, apa yang harus diselesaikan. Dengan kata lain berfikir strategis adalah berfikir tentang apa yang seharusnya dilakukan, dimana pertanyaan ini muncul setelah kita bertanya: apa yang sedang terjadi, kenapa terjadi, dimana terjadi, kapan terjadi. (sabariah, etika, 2016)

C. Menurut zikmund, 1994: Riset merupakan proses pengumpulan, pencatatan dan analisis data yang sistematik dan obyektif untuk membantu pembuatan keputusan (Sulisyanto, 2006)

D. Statistik dalam arti sempit sebagai sekumpulan angka-angka yang menggambarkan persoalan dan umumnya disusun dalam bentuk tabel, daftar \& grafik. Statitistik dalam arti luas sebagai salah satu cabang ilmu pengetahuan yang mempelajari cara pengumpulan data, pengolahan \& penyusunan serta penganalisaan, penarikan kesimpulan \& pembuatan keputusan berdasarkan analisis yang dilakukan, sehingga dapat disim- pulkan statistika merupakan cabang dari ilmu pengetahuan khususnya matematika yang terdiri dari sejumlah analisis yang menyediakan data untuk membantu kita dalam mempertimbangkan dan memutuskan pemecahan suatu masalah. (Asriana, Dian, 1997)

E. Manajemen produksi

F. Manajemen produksi merupakan salah satu bagian dibidang manajemen yang mempunyai peran dalam mengkoordinasi kegiatan untuk mencapai tujuan. Keputusan yang terkait adalah (1) kebijakan desain atau rancang produk, (2) kebijakan proses transformasi, (3) kebijakan terkait dengan perbaikan terus menerus dari system operasi (Riadi, Muchlisin, 2016)

G. Manajemen pemasaran

H. Manajemen pemasaran adalah merupakan alat analisis, perencanaan, penerapan dan pengendalian program yang dirancang untuk menciptakan, membangun dan mempertahankan pertukaran yang menguntungkan dengan target pasar sasaran dengan maksud untuk mencapai tujuan utama perusahaan yaitu memperoleh laba. (Rinaldi, Ferry, 2015)

Dalam dunia marketing selalu terdapat strategi pemasaran dan persaingan bisnis antar perusahaan yang terkait. Dalam skala pasar ada sekelompok usaha yang memasuki market leader, market challenger, market follower. Sesuai dengan posisinya maka (1) leader melakukan reaktif dengan balas dan bersaing harga, dan proaktifnya melakukan pengembangan pasar dan penelitian dan pengembangan, (2) challenger melakukan reaktif dengan follow the leader dan me too, sedangkan proaktifnya melakukan penyerangan, menatang, dan pengembangan produk baru, (3) follower melakukan reaktif dengan status uo dan me too, sedangkan proaktifnya melakukan pencarian pasar baru, segmen pasar baru dan market niche (Fryandiswastiko,2016)

\section{III.METODE PENELTIAN}

Metode penelitian yang digunakan dalam penelitian adalah:

1. Studi Literatur

Studi literatur dilakukan dengan membaca buku literatur, tentang kewirausahaan berkaitan dengan perkembangan lingkungan yang sudah 
sepenuhnya berada di era globalisasi milenial, sehingga tingkat kemampuan berkompetisi mempengaruhi daya tahan dalam berwirausaha sehingga teori yang terkait dalam penentuan kewirausahaan antaralainnya adalah: strategi, riset, statistic, dan manajemen, serta teknologi komunikasi yang dapat digunakan untuk pemasaran, dan olah data statistic sebagai penunjang keputusan.

2. Observasi

Observasi dilakukan dengan pengamatan, dari berbagai sumber yang diperoleh, untuk menemukan titik temu atau keterkaitan antar obyek yang diteliti melalui fenomena yang diamati secara umum.

3. Proses Analisa wacana baru dalam memberikan pelatihan kewirausahaan pada tingkat modal kerja rendah serta memiliki banyak keterbatasan, dengan melakukan keselarasannya antara study literature dengan hasil observasi fenomena niat dan usaha dari wirausaha kecil, yang kemudian dikembangkan agar ditemukan metode baru dalam pelatihan kewirausahaan yang dapat dimengerti secara sederhana oleh para wirausaha kecil menengah sebagai upaya efektif untuk mmembantu kontinuitas usaha mereka (keberlangsungan usaha).

A. Wirausaha.

\section{IV.HASIL DAN PEMBAHASAN}

Wirausaha adalah salah satu dari beberapa jalan untuk: 1) Menambah nilai ekonomi, 2) Mengatasi masalah ekonomi dengan berwirausaha dari pada mengganggur, 3) Mencover atau melindungi asset (kekayaan) dari penurunan nilai ekonomi, 4) Kemampuan membaca peluang usaha, sehingga hal tersebut tidak mungkin disia-siakan, 5) Melanjutkan hidup yang akan dilakukan oleh seorang yang telah berhenti bekerja, pensiun, atau menerima warisan tapi tidak bekerja.

B. Dua Golongan Wirausaha

Wirausaha banyak dilakukan oleh berbagai kalangan, baik dari anak muda kalangan atas, kalangan menengah atau pun kalangan bawah. Selain itu Orang tua atau level usia dewasa juga ikut merambah dunia wirausaha, baik dari kalangan atas, menengah atau pun dari kalangan bawah. Pada umumnya wirausaha yang cukup diminati oleh kalangan anak muda ini menimbulkan energy baru dalam menjungkit kemampuan ekonomi daerah pada khususnya dan negara pada umumnya, karena jika mereka sukses dalam berwirausaha, maka dampaknya akan mengurangi jumlah pengangguran, mengurangi resiko kejahatan dari salah pergaulan di kalangan anak muda, serta menambah pemasukan pajak. Keberhasilan yang diraih oleh anak muda tak lepas dari kemampuan mereka dalam tekhnologi, pengetahuan dan wacana yang luas serta komuikasi yang dinamis dan energik sebagai kalangan anak muda, sehingga salah satu keberhasilan mereka adalah mampu menjembati antar komunitas dari berbagai kalangan melalui wirausaha, se perti contohnya wirausaha bengkel motor yang dibangun oleh anak muda, dimana bengkel tersebut juga memfasilitasi service kombinasi dan penyediaan spare part onderdil motor-motor lawas atau langka, sehingga pemasaran bengkel mereka cukup bagus, karena pelanggan yang mereka ada dua tipe yaitu pelanggan penggila motor antic dan pelanggan motor biasa. Wirausaha dari berbagai kalangan dengan kondisi ekonomi berbeda, di Indonesia 
lebih banyak didominasi oleh masyarakat kalangan menengah kebawah. Kebanyakan dari mereka mempunyai latar belakang kurang menunjang dalam mempertahankan wirausaha, karena :

1. Keterbatasan modal kerja, pengetahuan, skill, kepribadian bisnis dan pengetahuan manajemen secara keseluruhan seperti manajemen bisnis \& pemasaran, manajemen keuangan, manajemen persediaan, manajemen strategi, dan masih banyak lagi ilmu yang harus dimiliki oleh seorang wirausaha

2. Wirausaha adalah pilihan satu-satunya dalam mengatasi masalah ekonomi, karena kondisi menganggur yang cukup lama sementara kebutuhan hidup tidak bisa ditunda

Tipekal dari wirausaha ini, tumbuh dari keterbatasan dan keterpaksaan. Wirausaha ini banyak kita jumpai dikehidupan sehari-hari, seperti: pedagang kasongan, warteg, pedagang kaki lima, dan pedagang emperan, penjahit keliling, tukan sol sepatu dan lain-lain.

\section{Permasalahan Wirausaha}

Permasalahan wirausaha adalah mampu mengatasi masalah persaingan yang tumbuh sangat dinamis, mampu mempertahankan pelanggan atau meningkatkan jumlah pelanggan, mampu mengelola keuangan dengan manajemen yang tepat serta mampu meningkatkan kualitas dan kuantitas produk yang disesuaikan dengan kebutuhan dan perkembangan zaman dari segi utilitas, efisien, efektif, selera, kepraktisan dan lain-lain. Permasalah tersebut akan mampu diatasi oleh wirausaha yang selalu mengup date ilmu pengetahuan dan tekhnologi. Akan tetapi bagi wirausaha yang terlahir dari keadaan yang serba terbatas cenderung rentan dalam bertahan diusaha wirausaha. Kebangkrutan usaha banyak dialami oleh kalangan masyarakat ini, dan itu sangat mem prihatinkan karena mereka tidak bisa mengatasi masalah ekonomi dan semakin terpuruk akibat dari menanggung kerugian. Banyak sekali usaha yang dilakukan oleh pemerintah dalam membantu wirausaha ini, antaralainnya dengan program jaringan pengaman social, modal kerja dari donasi atau subsidi, serta kemudahan mendapat modal kerja dengan bunga kecil. Akan tetapi masalah nya program pemerintah tidak akan sempurna jika tidak didukung oleh kemampuan wirausaha dalam mempertahankan usahanya.

D. Dampak Yang Berkaitan Dengan Masalah kewirausahaan

Tingginya angka pertumbuhan jumlah wirausaha dari berbagai kalangan masyarakat, seperti jamur yang tumbuh dimusim hujan, lalu gugur dimusim kering, sehingga banyak sekali masalah yang muncul dari setiap gerakan bisnis wirausaha dari kalangan ini, seperti konflik dalam berebut konsumen, ada kecurangan yang dilakukan dagangan yang kurang laku, seperti ikan diformalin, dan masih banyak contoh lainnya.

\section{E. Solusi}

Perekonomian dibangun oleh semua pelaku ekonomi yang bergerak secara dinamis dalam melaksanakan aktivitas ekonomi. Setiap langkah yang dilaksanakan oleh pelaku ekonomi tak lepas dari wacana, pelatihan \& pengembangan, ilmu pengetahuan \& Tekhnologi serta pengalaman sebagai soko guru. Akan tetapi tidak semua orang dapat mengikuti pendidikan tersebut dalam ruang institusi kependidikan. Banyak diantara mereka adalah orang-orang kecil 
yang sangat terbatas dalam pendidikan, pengetahuan dan modal kerja. Untuk lebih jelasnya kita dapat melihat proporsi para pelaku ekonomi dengan cara melihat dinamika ekonomi yang tidak lepas dari jumlah significant pada jumlah penduduk yang melaksanakan aktivitas ekonomi dari 225 juta jiwa penduduk Indonesia. Seperti kita ketahui pembangunan ekonomi sangat tergantung pada kemampuan dari sumber daya manusia dalam berperan menyumbangkan pemikiran dan tenaga dalam melaksanakan pembangunan. Dan pembangunan ekonomi bukan saja menjadi tanggung jawab pemerintah, melainkan adalah sebuah kewajiban rakyat Indonesia. Yang mana setiap usaha atau kerja dalam memenuhi kebutuhan hidup dengan melakukan aktivitas ekonomi adalah salah satu bentuk kontribusi dalam pembangunan ekonomi, karena tidak saja menyumbangkan pendapatan negara melalui pajak untuk keseimbangan social, taapi juga ikut menggerakan roda ekonomi secara berantai antar bidang, sektor, lintas bidang dan lintas geografis. Pembangunan ekonomi yang dilakukan dari masing-masing pihak memiliki peran yang berbeda-beda, dan tentunya saling melengka pi adalah tujuan dari kesempurnaan pembangunan ekonomi. Seperti perbankan BUMN yang diharuskan dalam mendukung dan berpihak pada tumbuh kembang dan kemajuan usaha wirausaha menengah kebawah. Banyak jalan sudah ditempuh oleh pemerintah dan berbagai pihak terkait untuk membantu wirausaha kecil menengah untuk dapat bertahan dalam usahanya. Akan tetapi masih banyak dikalangan masyarakat tersebut yang belum terjangkau oleh pihak- pihak yang peduli dalam kemajuan bersama. Adalah tugas dari pihak Institusi pendidikan yang memberi peran penting dalam kunci keberhasilan dalam membimbing wirausaha kecil menengah tersebut. Tridarma yang wajib dilakukan oleh pihak akademika adalah merupakan jembatan yang dapat menghubungkan pekerja dan wirausaha dengan dunia usaha kerja, dan usaha berjalan secara beriringan dalam membentuk energy positif dalam meningkatkan nilai ekonomi. Salah satu bagian dari Tridarma adalah melakukan pengabdian masyarakat. Dari kegiatan tersebut banyak sekali yang harus dilakukan oleh pihak akademika dalam usaha menjawab masalah yang dihadapi oleh masyarakat. Dengan demikian keterpurukan wirausaha kecil menengah dalam bertahan hidup pada setiap usaha, dapat dibantu dengan cara pelatihan pelatihan yang sangat bermanfaat dalam melakukan usaha. Dan karena tipekal masyarakat yang wirausahanya kecil dan menengah ini lebih dilatarbelakangi oleh keterbatasan pendidikan, maka dalam menyampaikan pelatihan tersebut hendaklah menggunakan kalimat yang sederhana, dan mudah di pahami serta menggunakan teori dasar yang sederhana saja. pelatihan tersebut antaralainnya adalah:

1. Memberi pelatihan matematika statistic manual untuk dapat menghitung jumlah pesaing, jumlah suplier, jumlah konsumen, serta strategi apa yang harus dilakukan,

2. Memberikan pelatihan cara perputaran barang yang dibeli atau diolah dalam kewirausahaan dengan perputaran barang yang dijual pada strategi pemasaran jitu yang diedukasikan secara sederhana

3. Memberi pelatihan matematika dan statistic dalam menghitung laba yang benar, detail tapi sederhana

4. Memberi pelatihan menghitung prive yang dapat ditoleransi sehingga tidak menganggu modal kerja pada batas kebutuhan harian dengan kebutuhan 
operasional usaha atau kerja pada wirausaha dengan modal kerja minim dengan implementasi subsidi pembeda dari pemerintah pada unit-unit usaha yang diberi pendampingan pada masa tertentu untuk berdikari

5. Memberi pelatihan menghitung perputaran piutang dan hutang yang bijaksana sehingga arus kas tidak mendapatkan masalah, dengan matematika sederhana

6. Memberikan pelatihan menghitung hutang usaha yang masih ditoleransi agar modal kerja tidak habis untuk membayar bunga pinjaman, dan arus kas tidak bermasalah

7. Berusaha mengenalkan statistic aplikasi yang tepat guna bagi kandidat atau calon wirausaha yang sudah dapat mengoperasionalkan computer untuk dapat melakukan seperangkat analisa kewirausahaan, setelah melakukan riset tempat, usaha dan lain sebagainya

Pelatihan tersebut dapat diberikan oleh pihak akademisi dalam kegiatan Tri Dharma pada kegiatan Pengabdian Masyarakat ataupun Kegiatan Kuliah Kerja Nyata (KKN), dengan berkoordinasi pada Pemerintah dan Pihak-Pihak lain yang perlu disertakan dalam upaya membantu kemandirian para wirausaha kecil menengah.

\section{KESIMPULAN}

Wirausaha adalah salah satu jalan dari banyak jalan dalam mengatasi masalah ekonomi dan dalam memenuhi kebutuhan hidup, sehingga ilmu kewirausahaan dibutuhkan oleh para pelaku ekonomi yang menggeluti dunia usaha atau berwiraswasta. Wirausaha banyak dilakukan oleh berbagai kalangan baik kalangan anak muda, dewasa, dan orang tua, serta kalangan ekonomi atas, menegah dan bawah. Ada dua jenis karakter wirausaha, yaitu: wirausaha yang mempunyai modal kerja, pengetahuan, skill, dan kemam puan tekhnologi, serta jenis karakter wirausaha yang berada pada kondisi terbatas baik modal kerja, pengetahuan, skill dan kemampuan dibidang tekhnologi. Karakter wirausaha yang memiliki nilai lebih memberi dam pak yang positif bagi perekonomian karena menyumbang pendapatan negara melalui pajak, mengurangi jumlah pengangguran dan menciptakan energy baru dalam menggerakkan roda ekonomi. Sementara itu karakter wirausaha yang memiliki keterbatasan modal kerja, pengetahuan, skill dan lain-lain, menciptakan kondisi memprihatinkan karena mereka tumbuh subur dalam melakukan wirausaha, tapi dalam waktu dekat mereka mengalami kebangkrutan, sehingga mereka tidak dapat mengatasi masalah ekonomi bahkan semakin ter puruk karena mengalami kerugian. Banyak sekali usaha yang dilakukan oleh pemerintah dan pihak yang terkait dalam membantu wirausaha kecil menegah dapat bertahan dalam usahanya, Usaha yang dilakukan meliputi jaringan pengamanan social, pinjaman modal kerja dengan bunga kecil, atau kerjasama antara pengusaha besar dengan wirausaha kecil menengah seperti induk dan anak. Akan tetapi masih banyak wirausaha kecil menegah yang masih belum terjangkau oleh banyak pihak yang membantu. Seperti diketahui bahwa pihak akademika memiliki peran dalam menjembatani pekerja dan wirausaha dengan dunia kerja dan bisnis, maka perannya sangat membantu dalam mendukung pembangunan ekonomi dengan salah satunya membimbing wirausaha kecil menengah agar da pat bertahan dalam usahanya. Melalui kegiatan pengabdian masyarakat yang merupakan salah satu dari bagian dari 
Tri darma, maka pihak akademika dapat membantu memberikan pelatihan kewirausahaan salah satunya melalui perkenalan ilmu matenatika dan statistika sebagai bagian dari cara untuk menunjang kewirausahaan .

\section{DAFTAR PUSTAKA}

Sabariah, etika, 2016: Manajemen Strategi, Pustaka Pelajar Yogyakarta Jogiyanto, 2009: Sistem Teknologi Informasi Andi offset, Yogyakarta Riadi, Muchlisin, 2016, "Pengertian dan fungsi Manajemen Produksi Pada http//www.kajianpustaka.com, 2016

Rinaldi, Ferry, 2015, "Manajemen pemasaran konsep Orientasi” pada http:// www.kembar. Pro, 2015,

Fryandiswastiko,2016), Skala Pasar dikenal ada istilah Market Leader, Chaleenger, Market Follower dan Market Nicher pada http://fryandiswastiko.wordpress.com/2016/05/08/skala-pasar-dikenal-adaistilah-market-leader-market-challenger-markey-follower-dan-markety nicher-topic-7/). 